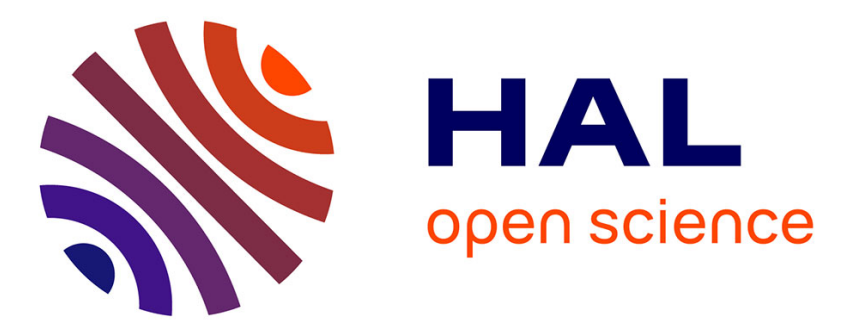

\title{
Annual particulate matter and diatom export in a high nutrient, low chlorophyll area of the Southern Ocean
}

\author{
M. Rembauville, I. Salter, F. Dehairs, J.-C. Miquel, S. Blain
}

\section{To cite this version:}

M. Rembauville, I. Salter, F. Dehairs, J.-C. Miquel, S. Blain. Annual particulate matter and diatom export in a high nutrient, low chlorophyll area of the Southern Ocean. Polar Biology, 2017, 10.1007/s00300-017-2167-3 . hal-01579390

\section{HAL Id: hal-01579390 \\ https://hal.sorbonne-universite.fr/hal-01579390}

Submitted on 31 Aug 2017

HAL is a multi-disciplinary open access archive for the deposit and dissemination of scientific research documents, whether they are published or not. The documents may come from teaching and research institutions in France or abroad, or from public or private research centers.
L'archive ouverte pluridisciplinaire HAL, est destinée au dépôt et à la diffusion de documents scientifiques de niveau recherche, publiés ou non, émanant des établissements d'enseignement et de recherche français ou étrangers, des laboratoires publics ou privés. 


\section{Annual particulate matter and diatom export in a high nutrient, low}

2 chlorophyll area of the Southern Ocean

3 M. Rembauville ${ }^{1, *}$, I. Salter ${ }^{1,2}$, F. Dehairs ${ }^{3}$, J.-C. Miquel ${ }^{4}$ and S. Blain ${ }^{1}$.

${ }^{1}$ Sorbonne Universités, UPMC Univ Paris 06, CNRS, Laboratoire d'Océanographie Microbienne (LOMIC),

5 Observatoire Océanologique, F-66650, Banyuls/mer, France

$6 \quad{ }^{2}$ Alfred Wegener Institute, Helmholtz Centre for Polar and Marine Research, Am Handelshafen 12, 27570

7 Bremerhaven, Germany

$8{ }^{3}$ Analytical, Environmental and Geo - Chemistry; Earth System Sciences Research Group, Vrije Universiteit

9 Brussel, Belgium

${ }^{4}$ International Atomic Energy Agency, Environment Laboratories, 4, quai Antoine 1er, 98000 Monaco

${ }^{*}$ Corresponding author: rembauville@obs-banyuls.fr

\section{Abstract}

Upper ocean plankton assemblages are known to influence the export of carbon and biominerals from the mixed layer. However, relationships between plankton community structure and the magnitude and stoichiometry of export remain poorly characterized. We present data on biogeochemical and diatom export fluxes from the annual deployment of a sediment trap in a High Nutrient, Low Chlorophyll (HNLC) area upstream of the Kerguelen Plateau (KERFIX station). The weak and tidal-driven circulation provided favorable conditions for a quantitative analysis of export processes. Particulate organic carbon (POC) fluxes were highest in spring and summer. Biogenic silica (BSi) fluxes displayed similar seasonal patterns, although BSi:POC ratios were elevated in winter. Fragilariopsis kerguelensis dominated the annual diatom export assemblage (59.8\% of the total valve flux). We identified clusters of diatom species that were positively or negatively correlated to the $\mathrm{BSi}$ POC ratio. Our results indicate that the differential role of certain diatom species for carbon and silicon export, previously identified from iron-fertilized productive areas, is also 

valid in HNLC regimes. Although annual POC export below the mixed layer of the HNLC site is two-fold lower that the one previously reported in a naturally iron-fertilized area of the Kerguelen Plateau, the fraction of seasonal net community production exported is similar at both sites $(\sim 1.5 \%)$. These findings suggest that natural iron fertilization increases the strength but not the efficiency of carbon export from the mixed layer.

Keywords:

35 Kerguelen Plateau, Export fluxes, Diatoms, HNLC, Export efficiency. 


\section{Introduction}

The Southern Ocean is the largest high nutrient, low chlorophyll (HNLC, Minas et al. 1986) area of the Global Ocean (Martin et al. 1990; Minas and Minas 1992). In open ocean areas of the Southern Ocean HNLC regime, low primary production is mainly attributable to iron limitation (Martin et al. 1990; de Baar et al. 1990; de Baar et al. 1995). However, in the vicinity of subantarctic islands and plateaus regions, iron inputs from shelf sediments and glacial melt represent a natural fertilization mechanism that can sustain long-lasting (several months) phytoplankton blooms (Blain et al. 2001; Blain et al. 2007; Pollard et al. 2007; Tarling et al. 2012). The fate of organic matter and carbon cycling within these blooms typically associated with strong air-to-sea $\mathrm{CO}_{2}$ fluxes (Jouandet et al. 2008; Merlivat et al. 2015) have been addressed during multidisciplinary studies such as the KEOPS1 and KEOPS2 cruises near the Kerguelen Islands (Blain et al. 2008), the CROZEX cruise around the Crozet islands (Pollard et al. 2009), and the DISCOVERY cruise near South Georgia (Tarling et al. 2012).

During the KEOPS cruises in spring and summer, short term measurement of carbon export using the ${ }^{234} \mathrm{Th}$ approach indicates a two-fold increase in carbon export in naturally fertilized waters compared to HNLC waters (Blain et al. 2007; Savoye et al. 2008; Planchon et al. 2015). However, an annual deployment of a moored sediment trap just below the mixed layer at the productive station A3 on the central Kerguelen Plateau $\left(50^{\circ} 38 \mathrm{~S}-72^{\circ} 02 \mathrm{E}\right.$, Fig. 1) reported a low annual particulate organic carbon (POC) flux of $98.2 \mathrm{mmol} \mathrm{m}^{-2} \mathrm{yr}^{-1}$ (Rembauville et al. 2015b). During the CROZEX study, ${ }^{234}$ Th-derived export revealed similar patterns with a threefold higher export in the naturally fertilized area downstream of the Crozet Plateau when compared to the HNLC waters (Morris et al. 2007). Long-term moored sediment trap deployments (>3000 m) also revealed a twofold higher annual POC export in 
the fertilized site when compared to the HNLC site, although POC fluxes were low (28.8 vs. $11.6 \mathrm{mmol} \mathrm{m} \mathrm{yr}^{-1}$; Pollard et al., 2009).

Conceptual relationships between diatom community structure and carbon export have been the subject of previous studies (Boyd and Newton 1995; Boyd and Newton 1999; Quéguiner 2013). Detailed descriptions of diatom export assemblages from iron-fertilized blooms in the Southern Ocean have highlighted the importance of diatom life cycle ecology for the regulation of carbon and silicon export (Smetacek et al. 2004; Salter et al. 2007; Salter et al. 2012; Smetacek et al. 2012; Assmy et al. 2013; Rembauville et al. 2015a). However, despite significant levels of biomass production, low values of POC export have raised questions concerning the efficiency of such systems to transfer carbon to depth through the biological pump (Lam and Bishop 2007; Jacquet et al. 2011; Rembauville et al. 2015b) . Indeed, the positive relationship between production and export efficiency observed in most of the global ocean (Laws et al. 2011) appears to be invalid in the Southern Ocean (Maiti et al. 2013). Furthermore, a recent global analysis comparing the fraction of microphytoplankton with POC flux attenuation shows that highest attenuation coefficients occur in high latitude regions (Guidi et al. 2015). These recent observations are consistent with the concept of high biomass, low export (HBLE) regimes identified in certain regions of the Southern Ocean (Lam and Bishop 2007), and thereafter at other locations of the global ocean (Lam et al. 2011). It has been suggested that in HBLE regimes, higher productivity does not necessarily leads to higher carbon export but rather results in enhanced POC fragmentation, remineralization (Obernosterer et al. 2008), and/or transfer to higher trophic levels (Huntley et al. 1991). Certain regional studies support this scenario. For example, in a naturally fertilized and diatom-dominated productive system downstream of South Georgia, highest zooplankton biomass is associated with the lowest particle export efficiency (Cavan et al. 2015). Although these snapshots offer intriguing insights into ecosystem function, they may be confounded by 
the relatively short time-scales (days to weeks) characterizing the observations. Comparative studies linking chemical fluxes to ecological vectors over seasonal and annual timescales remain necessary to compare export efficiencies of HNLC and productive systems.

KERFIX (Kerguelen fixed station) was a five year observation program that ran from 1991 to 1995 (Jeandel et al. 1998) and was established as a component of the international JGOFS program. The KERFIX station is located on the southwestern flank of the Kerguelen Plateau (Fig. 1b). A key objective of the program was to describe the factors responsible for low primary production in a region of the Antarctic Zone (AAZ) characterized by high macronutrient concentrations. The monthly sampling program included hydrological variables (Jeandel et al. 1998; Park et al. 1998), dissolved inorganic carbon and alkalinity (Louanchi et al. 2001) as well as biological (Fiala et al. 1998; Razouls et al. 1998; Kopczyńska et al. 1998) and geochemical parameters (Dehairs et al. 1996). These data were used to build and calibrate numerical models to explain how the diatom spring bloom contributed to significant silicon export despite an overall dominance of nanoplankton in these HNLC waters (Pondaven et al. 1998; Pondaven et al. 2000).

During the last two years of the KERFIX program (1993-1995), sediment traps were deployed below the mixed layer with the aim of providing a coupled description of production and export. Ternois et al. (1998) reported particulate organic carbon, hydrocarbon, sterol and coccoliths export fluxes from a shallow sediment trap (175 m) over a 10-month time series (April 1993 to January 1994). A high contribution of fresh (i.e., labile) marine organic material was recorded during the summer and autumn months. During the winter months an unresolved and complex mixture characterized the organic composition of particles and was linked to zooplankton grazing. Despite these valuable insights, missing samples and position of the sediment trap within the winter mixed layer (182 m, Park et al. 1998) prevented a quantitative analysis of the export processes. A second sediment trap deployment was carried 
out the following year at a slightly deeper position of $280 \mathrm{~m}$ covering a nearly complete annual cycle. These samples provide a valuable opportunity to study the link between the diatom flux assemblages and the intensity and stoichiometry of export in iron-limited HNLC waters located $200 \mathrm{~km}$ upstream of the productive central Kerguelen Plateau.

In the present study, we report the biogeochemical fluxes (POC, particulate inorganic carbon - PIC, biogenic silica - BSi) and diatom community composition of material collected by a moored sediment trap deployed below the mixed layer in a low productivity area and covering an entire annual cycle. Our aims are (1) to assess the reliability of the collected fluxes by analyzing the physical characteristics of the deployment, (2) to investigate how diatom community composition influences the magnitude of the POC flux and (3) examine the seasonal export efficiency of this HNLC area in comparison to a more productive regime on the central Kerguelen Plateau.

\section{Materials and methods}

\section{Sediment trap deployment and chemical analyses}

As part of the KERFIX program (Jeandel et al. 1998), a sediment trap was moored at the HNLC station $\left(50^{\circ} 40^{\prime} \mathrm{S}-68^{\circ} 25^{\prime} \mathrm{E}\right)$, south of the Polar Front in the AAZ. The KERFIX station is characterized by low phytoplankton biomass (Fiala et al. 1998; Kopczyńska et al. 1998) in comparison to the productive central Kerguelen Plateau (Fig. 1b). The sediment trap (Technicap PPS5, $1 \mathrm{~m}^{2}$ collecting area) was positioned at $280 \mathrm{~m}$ over a bottom depth of 2300 m. To prevent the intrusion of macrozooplankton and mesopelagic fish, the trap funnel was equipped with a baffle ( $8 \mathrm{~mm}$ diameter cells) with an aspect ratio (height/diameter) of 6.2. A current meter (Anderaa RCM7) was placed $20 \mathrm{~m}$ below the sediment trap and recorded current speed, pressure and temperature with a $2 \mathrm{~h}$ interval. The sediment trap contained a 24- 
sample carousel. Sample cups $(280 \mathrm{~mL})$ were filled with a preservative solution of hyper saline seawater and $5 \%$ formalin buffered to $\mathrm{pH} 8$ with filtered $(0.2 \mu \mathrm{m})$ sodium tetraborate. The collection period was from the $19^{\text {th }}$ February 1994 to the $22^{\text {nd }}$ January 1995 (total $=337$ days). Sampling intervals were programmed to reflect anticipated flux patterns with the highest temporal resolution in spring and summer (7-10 days) and the lowest in winter (30 days). Following the recovery of the sediment trap, $50 \mathrm{~mL}$ of supernatant was withdrawn from the sample and $1 \mathrm{~mL}$ of buffered preservative solution was added. Samples were sieved through a $1.5 \mathrm{~mm}$ mesh and both fractions were examined under binocular microscope to manually remove swimmers (organisms actively entering the trap). After the removal of swimmers, both size fractions were combined and the samples were split into 1/8 aliquots using a Folsom splitter (McEwen et al. 1954) with an error of <5 \% (Sell and Evans 1982).

Prior to chemical analysis, wet aliquots were centrifuged and rinsed with milli-Q water (10 minutes at $5000 \mathrm{rpm}$, three times) to remove excess salt and formalin. The supernatant was withdrawn and the resulting pellet freeze-dried (FTS systems DURA DRY). Mass flux was determined from the weight of the lyophilized pellet (Mettler-Toledo AE163 balance, 10 $\mu \mathrm{g}$ precision). For POC, 3-5 mg of freeze-dried pellet (Sartorius M3P balance, $1 \mu \mathrm{g}$ precision) was placed in silver cups and phosphoric acid $(1 \mathrm{~N})$ added in excess to dissolve $\mathrm{CaCO}_{3}$. $\mathrm{POC}$ content was measured with a CHN analyzer (Heraeus CHN-O-Rapid) calibrated with acetanilide (Miquel et al. 1994). The precision derived from repeated measurements of carbon on the acetanilide standard was $1.4 \%$. For BSi, a kinetic method (DeMaster 1981) was used as described in Mosseri et al. (2005). Briefly, 5-10 mg of freeze-dried material was weighed and placed in centrifuge tubes with $40 \mathrm{~mL}$ of ultrapure $\mathrm{NaOH}(0.2 \mathrm{~N})$. The samples were placed in a water bath at $95^{\circ} \mathrm{C}$ and $200 \mu \mathrm{L}$ of solution were removed after $1,2,3$ and $4 \mathrm{~h}$ and placed into scintillation vials and made up to $10 \mathrm{~mL}$ with milli-Q water. Silicic acid concentrations were determined colorimetrically on a Skalar autoanalyser following (Aminot 
and Kerouel 2007). The BSi content was determined by fitting a linear regression to silicic acid concentration as a function of extraction time. The intercept of this relationship is taken as BSi content without interference of silicon leaching from lithogenic material (DeMaster 1981). PIC was determined from direct measurement of calcium (Ca). $5 \mathrm{mg}$ of freeze-dried material was mineralized in Teflon vials by adding $0.5 \mathrm{~mL}$ of $65 \% \mathrm{HNO}_{3}$ and $0.5 \mathrm{~mL}$ of 40 $\%$ HF. Samples were ultrasonicated and dried at $40^{\circ} \mathrm{C}$ overnight. This residue was dissolved in $10 \mathrm{~mL}$ of $0.1 \mathrm{~N} \mathrm{HNO}_{3}$ and the calcium concentrations determined by coupled plasmaoptical emission spectrometry (ICP-OES, HORIBA Jobin Yvon 48 and 38). The flux for the unsampled month (February 1995) was estimated from the mean flux of the time series and used to estimate the annually integrated values POC, PIC and BSi fluxes.

\section{Slides preparation and diatom taxonomy}

Samples for diatom taxonomy were prepared using a micropaleontological oxidative method as previously described in Romero et al. (1999). Briefly, a 1/8 wet aliquot was placed in a beaker and oxidized with potassium permanganate $\left(20 \mathrm{~mL}, 65 \mathrm{~g} \mathrm{~L}^{-1}\right)$, hydrochloric acid (50 $\mathrm{mL}, 37 \%)$ and hydrogen peroxide $(40 \mathrm{~mL}, 35 \%)$ at $95{ }^{\circ} \mathrm{C}$. Samples were then rinsed with milli-Q water and centrifuged several times until the $\mathrm{pH}$ was equivalent to that of the milli-Q water. Three slides were prepared per sample using a random settling method (Bárcena and Abrantes 1998). Slides were observed under an inverted microscope with phase contrast (Olympus BH2) at 400 and $1000 \mathrm{x}$ magnification. A minimum of 400 valves were enumerated per sample following Schrader and Gersonde (1978) and diatoms were identified to the species level following Hasle and Syvertsen (1997). Diatom counts were not possible in the last two sample cups (January 1995) due to the very low quantity of material.

Contrary to more recent sediment trap studies in which diatom counts were made through direct observation of untreated samples (Salter et al. 2007; Salter et al. 2012; Rembauville et al. 2015a; Rembauville et al. 2016a), at the time of the KERFIX program a 
micropaleontological counting technique was used. The micropaleontological method was originally developed for samples originating from sediment cores. The oxidation and multiple centrifugation steps remove organic cell contents and separate diatom cells into valves and girdle bands. Although these chemical oxidation steps aid in the detailed taxonomic characterization of specimens, the destruction of organic matter prevents the distinction of full and empty frustules and consequently the contribution of individual diatom species to total POC export fluxes cannot be quantified (Rembauville et al. 2015a). Moreover the treatment might selectively alter the lightly silicified species (Rembauville et al. 2015a), or lead to the overestimation of some species with numerous girdle bands per cell such as Dactyliosolen antarcticus. A cross validation of the two counting techniques would certainly be of interest at this HNLC site. Unfortunately, however, there are no longer samples available to make such a comparison. The biogeochemical and diatom taxonomy data are accessible at http://www.obs$\underline{\text { vlfr.fr/cd_rom_dmtt/OTHER/KERFIX/trapdata/. }}$

\section{Numerical and statistical analyses}

To identify the major periods of current speed variations, current speed data was analyzed using fast Fourier transform (FFT). The resulting power spectrum was compared to a red noise, a theoretical signal in which the amplitude decreases with increasing frequency. The red noise was considered as a null hypothesis and scaled to the power spectrum to identify periods that differs significantly from a random distribution (Schulz and Mudelsee 2002).

To categorize the major diatom groups that were exported with similar seasonality, a clustering analysis (Bray-Curtis distance, unweighted pair group method with arithmetic mean - UPGMA agglomeration criteria) was performed on the relative abundance of diatom taxa accounting for more than $1 \%$ of the total annual diatom export (11 species). The association of these major species with the BSi:POC ratio was studied using partial least square regression (PLSR). The principle of PLSR is to decompose the predictors matrix (here the 
valve fluxes of the 11 main diatom taxa) into few principal components and then perform a regression of the response variable (here the $\mathrm{BSi}: \mathrm{POC}$ ratio) on these components. $\mathrm{A}$ significant advantage of PLSR is to avoid the weight of colinearity of the multiple predictors which is a common feature of species assemblage data (Abdi 2010). Previous studies have shown PLSR to be a useful statistical approach linking biological diversity to environmental factors in the ocean (Salter et al. 2014a; Rembauville et al. 2015a). The PLSR was performed on standardized variables (mean subtracted, divided by the standard deviation).

\section{Results}

\section{Hydrological context}

The trap depth gradually decreased by 4 meter ( $284 \mathrm{~m}$ to $280 \mathrm{~m}$ ) from February to June 1994 and remained at $280 \mathrm{~m}$ until the recovery (Fig. 2a). No strong depth oscillation was observed except during two short deepening events (4-6 m amplitude) that occurred in February and September 1994. Temperature remained mostly constant between 1.8 and $2.2{ }^{\circ} \mathrm{C}$ except during one short event from 20 to 30 March 1994 where temperature decreased to $1{ }^{\circ} \mathrm{C}$ (Fig. 2b). This event was not associated with any particular depth or current speed variation.

Current speed ranged from $<1$ to $30 \mathrm{~cm} \mathrm{~s}^{-1}$ and displayed a highly variable signal over short time scales (Fig. 2c). There were no obvious seasonal patterns in current speed distribution and $74 \%$ of the current speed data was $<12 \mathrm{~cm} \mathrm{~s}^{-1}$.

The progressive vector diagram displayed numerous tidal ellipses over short timescales (hours to days, Fig. 3a). The integrated displacement over one year corresponds to a $450 \mathrm{~km}$ northward advection. Higher frequencies were observed for northwestward flow when current speeds exceeded $20 \mathrm{~cm} \mathrm{~s}^{-1}$ (Fig. 3b). Conversely, the southwestward flow displayed lower frequencies and was mainly characterized by speeds $<10 \mathrm{~cm} \mathrm{~s}^{-1}$. Six 
significant peaks corresponding to tidal components were observed. Short timescale peaks (6.2 $\mathrm{h}$ and $6.8 \mathrm{~h}$ period) corresponded to a combination of tidal components of longer periods. The moon 2 (M2, $12.4 \mathrm{~h}$ period) tidal component was present, and long-term components ( $3 \mathrm{~d}$ and $14 \mathrm{~d}$ period) were also observed.

\section{Biogeochemical fluxes}

Chlorophyll $a$ concentrations started to increase in October 1993 from $0.2 \mu \mathrm{g} \mathrm{L}^{-1}$ to reach $1 \mu \mathrm{g}$ $\mathrm{L}^{-1}$ in mid December 1993 when mixed layer depth (MLD, data from was the shallowest (60 m, Fig. 4a). A significant proportion of the phytoplankton biomass (70 \%) was located below the MLD. The MLD gradually decreased to $185 \mathrm{~m}$ in August 1994 concomitantly with a decrease in chlorophyll $a$ to $0.2 \mu \mathrm{g} \mathrm{L}^{-1}$. A second spring bloom occurred in November 1994 reaching a maximum of $1.2 \mu \mathrm{g} \mathrm{L}^{-1}$ in December and was also associated with a shoaling of the MLD.

POC flux was highest in late summer (February 1994) following the sediment trap deployment $\left(0.9 \mathrm{mmol} \mathrm{m}^{-2} \mathrm{~d}^{-1}\right)$ and decreased to $0.10-0.25 \mathrm{mmol} \mathrm{m}^{-2} \mathrm{~d}^{-1}$ in autumn (Table 1, Fig. 4b). Winter fluxes were negligible $\left(<0.1 \mathrm{mmol} \mathrm{m}^{-2} \mathrm{~d}^{-1}\right.$ from July to October 1994). A small increase in POC flux of up to $0.25 \mathrm{mmol} \mathrm{m}^{-2} \mathrm{~d}^{-1}$ occurred concomitantly with the phytoplankton bloom in November-December 1994. Annual POC export flux was estimated at $51.6 \mathrm{mmol} \mathrm{m}^{-2} \mathrm{yr}^{-1}$. PIC fluxes were low in late summer $\left(25-75 \mu \mathrm{mol} \mathrm{m} \mathrm{m}^{-2} \mathrm{~d}^{-1}\right.$, Table 1, Fig. 4b), negligible in winter, and increased to $50-160 \mu \mathrm{mol} \mathrm{m}^{-2} \mathrm{~d}^{-1}$ during the spring bloom (November-December 1994). The annual PIC export flux was estimated at $7.7 \mathrm{mmol} \mathrm{m}^{-2} \mathrm{yr}^{-1}$.

BSi flux showed a similar seasonal pattern to POC with highest fluxes in late summer (1 - $2 \mathrm{mmol} \mathrm{m}^{-2} \mathrm{~d}^{-1}$ in February - March 1994), moderate fluxes in autumn $\left(\sim 0.5 \mathrm{mmol} \mathrm{m}^{-2} \mathrm{~d}^{-}\right.$ ${ }^{1}$ ), and negligible fluxes in winter (Table 1, Fig. 4c). A small but noticeable increase was observed during the spring bloom (up to $0.4 \mathrm{mmol} \mathrm{m}^{-2} \mathrm{~d}^{-1}$ ). The BSi:POC molar ratio 
displayed a clear seasonal pattern with a value close to 2 in late summer, increasing to 3.9 in autumn. Winter values were $<0.5$, increasing to $\sim 1.8$ during the spring bloom. The annually integrated BSi:POC ratio (annual BSi flux divided by annual POC flux) was 2.2.

\section{Diatom fluxes}

The seasonal pattern of total diatom valve flux mirrored that of POC with the highest flux observed in the first sample cup $\left(1.3 \times 10^{8}\right.$ valve $\mathrm{m}^{-2} \mathrm{~d}^{-1}$, Table 1, Fig. 5a), decreasing gradually in autumn to reach very low values in winter $\left(1 \times 10^{6}\right.$ valve $\left.\mathrm{m}^{-2} \mathrm{~d}^{-1}\right)$. Total diatom valve flux increased again during the spring bloom to $3.5 \times 10^{7}$ valve $\mathrm{m}^{-2} \mathrm{~d}^{-1}$.

Fragilariopsis kerguelensis dominated the diatom export assemblage on an annual scale $(59.8 \%)$, with the highest relative contribution in winter $(>70 \%$ of the diatom assemblage in August). This species presented a notable export peak in summer $\left(6 \times 10^{7}\right.$ valve $\mathrm{m}^{-2} \mathrm{~d}^{-1}$, Fig. 5b) and lower values during spring $\left(1 \times 10^{7}\right.$ valve $\left.\mathrm{m}^{-2} \mathrm{~d}^{-1}\right)$. Other diatom species displayed export peaks during both spring and summer such as Thalassionema nitzschiodes (16\% of the diatom community in November), Fragilariopsis rhombica (5\%), Thalassiosira gracilis (4\%), Navicula directa (6\%) and Dactyliosolen antarcticus (9\%). By contrast, certain species presented a preferential summer export peak such as Chaetoceros subgenus Hyalochaete resting spores (CRS, $10 \%$ of the diatom assemblage in February), Pseudo-nitzschia lineola (10 \%), Pseudo-nitzschia heimii (5\%), and Chaetoceros socialis $(2.7 \%)$

Two main clusters were identified based on the largest distance break after the first node of the dendrogram constructed with the diatom valve flux in each sediment trap sample cup (Fig. 6a). The coefficient of determination $\left(\mathrm{R}^{2}\right)$ of the PLSR model was 0.68. A first cluster was composed of $F$. rhombica, $F$. kerguelensis, $T$. gracilis, $N$. directa, $T$. nitzschioides and D. antarcticus. These species displayed two peaks in their export flux in late summer 
1994 and spring 1995 (Fig. 5) and were positively correlated with the BSi:POC ratio $(0.18<\beta$

$<0.5$, Fig. $6 b)$, except for $T$. nitzschioides $(\beta=-0.03)$. A second cluster contained $F$. pseudonana, P-N. heimii, P.-N. lineola; T. oestrupuii, and CRS. These species displayed a clear mid-summer export peak in February 1994 and very low fluxes in spring 1995. They were negatively correlated with the BSi:POC ratio $(-0.18<\beta<-0.05)$. Finally, $C$. socialis constituted the outer branch of the dendrogram, displayed a clear mid-summer export peak and was negatively correlated with the BSi:POC ratio $(\beta=-0.23)$.

\section{Discussion}

\section{Hydrological context and sediment trap record reliability}

The mean temperature of $\sim 2{ }^{\circ} \mathrm{C}$ observed over the course of the year is consistent with the temperature of water masses just below the winter waters (WW) reported at the same station (Park et al. 1998). The abrupt decrease in temperature to $1^{\circ} \mathrm{C}$ at the end of March is unusual considering the lowest recorded temperature of winter water (WW) is $1.8{ }^{\circ} \mathrm{C}$ (Park et al. 1998). Nevertheless, Park et al. (1998) reported the largest steric height negative anomaly during the same period (February - March 1994). Such a major and abrupt change in water mass circulation could entrain very cold WW northward and explain the observed temperature decrease. Although the exact reason for this temperature change remains unresolved, it did not affect the sediment trap depth and was not associated with any change in current speed and therefore probably poorly affected the sediment trap collection efficiency. Current speed variations were associated with tidal components (Fig. 3c). A similar finding was found on the central Kerguelen Plateau, with a major contribution of the M2 tidal component (Rembauville et al. 2015b). At KERFIX, the tidal components are more diverse and contain components of diurnal and semi-diurnal waves. The additional complexity may arise from the 
proximity of the plateau flank where most of the tidal energy is dissipated (Maraldi et al. 2011). Overall, the observations are entirely consistent with short-term observations of tidaldriven water masses displacement (Park et al. 2008a) and emphasize the importance of tides for circulation around the Kerguelen Plateau.

The KERFIX sediment trap deployment location was characterized by a major northwestward flow. As the Antarctic Circumpolar Current encounters the Kerguelen Plateau, most of the surface water continues an eastward flow over the central plateau, although deeper currents appear to exhibit a northward inflection when they meet the western flank of the plateau at the KERFIX location (Park et al. 2008b). The pseudo-Lagrangian view of the progressive vector diagram is therefore consistent with the current understanding of circulation in the study area. The progressive vector diagram (Fig. 3a) reflects the $450 \mathrm{~km}$ northward displacement in one year which corresponds to advection with a mean speed of 1.4 $\mathrm{cm} \mathrm{s}^{-1}$. This is comparable to the range of sinking speeds reported for marine particles in the region (0.01-1.1 $\mathrm{cm} \mathrm{s}^{-1}$, Laurenceau-Cornec et al. 2015) and thus advection should not have transported particles far away from the overlying surface before they reach the shallow trap depth (280 m). From July to November 1994, the flow is clearly westward and we cannot rule-out a possible contribution from particles originating from the near central Kerguelen Plateau. However, this contribution would be minor at annual scale because the POC flux during the corresponding period is the lowest recorded $\left(<0.05 \mathrm{mmol} \mathrm{m}^{-2} \mathrm{~d}^{-1}\right)$.

It is widely acknowledged that shallow sediment trap deployments are prone to hydrodynamic artifacts (Gardner 1980; Buesseler et al. 2007). The low aspect ratio (1.7) and conical funnel shape of the PPS5 could render this design more susceptible to hydrodynamic artifacts (Hawley 1988; Buesseler et al. 2007). A current speed of $12 \mathrm{~cm} \mathrm{~s}^{-1}$ is often invoked as an upper limit for the reliability of moored sediment trap (Baker et al. 1988). During the KERFIX deployment, $74 \%$ of the current speed data is below this threshold. However, some 
current speeds increased episodically to $20 \mathrm{~cm} \mathrm{~s}^{-1}$ in February/March and October/November 1994. These two periods correspond to the highest and lowest POC fluxes, respectively. Although the hydrological data generally suggest that the sediment trap was not subject to major hydrodynamic biases, episodic events ( 10 days) of current increase might have impacted the sediment trap collection efficiency at short time scale (Gardner 1980; Baker et al. 1988).

The sediment trap used in the present study was equipped with an $8 \mathrm{~mm}$ baffle (aspect ratio of the baffle: 6.2). This design is typically considered to prevent the intrusion of large organisms (e.g. fishes) into sediment traps, but has no effect on smaller swimmers feeding on the trap funnel (Buesseler et al., 2007) or swimmers intrusion within the sampling cup (Nodder and Alexander 1999). Although swimmers were removed before chemical analyzes, unfortunately there is no record of swimmer abundance and diversity. These data would have helped to address the potential impact of swimmers on trapping efficiency, and provided additional information on the seasonal succession of biological communities (e.g. Matsuno et al. 2014; Rembauville et al. 2015b). Unfortunately with the present dataset we cannot rule-out a potential biological bias associated with the swimmers and we cannot explicitly address trapping efficiencies as has been carried out in previous studies (Coppola et al. 2002; Buesseler et al. 2010).

\section{Export seasonality and diatom export assemblage}

The annual record presented in this study covers 337 days from summer 1994 to summer 1995 and is therefore considered representative of the main seasonal transitions at the KERFIX site. Both POC and BSi fluxes display clear late-summer maxima. It seems probable that any export production originating from the 1993 phytoplankton bloom would have occurred during the summer prior to the sediment trap deployment. The timing of the export in spring 1994 is closely associated with the development of the spring phytoplankton bloom, 
in contrast to the one month lag observed at the productive A3 station of the central Kerguelen Plateau (Rembauville et al. 2015b). We previously attributed the temporal lag at A3 to the formation and export of diatom resting spores that dominate POC flux (60-80\%) during export events that occur 1 month later than surface chlorophyll $a$ peaks (Rembauville et al. 2015a). A similar time lag and export mechanism was also observed in the naturally fertilized waters of South Georgia (Rembauville et al. 2016a). The coupling between production and export at the KERFIX site would suggest that other export vectors aside from diatom spore formation may be important in HNLC regimes.

CRS represent a minor contribution to the exported diatom community at the KERFIX station $(5.6 \%)$, whereas they were the dominant component $(70 \%)$ at the productive A3 station (Rembauville et al. 2015a). The vegetative stages of Chaetoceros Hyalochaete are a minor fraction of the mixed layer diatom assemblage at KERFIX (Fiala et al. 1998) where the deep waters $(2300 \mathrm{~m})$ probably prevent the exported resting stage to be transported back in the mixed layer to complete the life cycle (McQuoid and Hobson 1996). It was further hypothesized that a strong decrease in silicic acid concentration in late summer in naturally iron-fertilized areas could trigger diatom resting spore formation (Salter et al. 2012;

Rembauville et al. 2015a). The silicic acid concentration in the mixed layer in summer at KERFIX never reaches values lower than $9 \mu \mathrm{mol} \mathrm{L}^{-1}$ (Jeandel et al. 1998) whereas it is almost depleted $\left(\sim 1 \mu \mathrm{mol} \mathrm{L}{ }^{-1}\right)$ over the central Kerguelen Plateau (Mosseri et al. 2008). These results are consistent with the observation of a strict dominance of Eucampia antarctica var. antarctica resting spores to the diatom export assemblage in the productive stations downstream the Crozet Islands where silicic acid is depleted in summer, and negligible contribution of resting spores in the upstream HNLC area (Moore et al. 2007; Salter et al. 2007). 
The exported diatom assemblage at the KERFIX station was strictly dominated by $F$. kerguelensis (59.8\%), consistent with its dominance in the mixed layer (Fiala et al. 1998; Kopczyńska et al. 1998). Fragilariopsis kerguelensis typically dominates diatom export assemblages in the vast HNLC areas of the Southern Ocean (Romero and Armand 2010; Grigorov et al. 2014; Rigual-Hernández et al. 2015a,b), and it is the most abundant species in the silica ooze under the Antarctic circumpolar current (Zielinski and Gersonde 1997). Its strong and thick frustules, together with its ability to form long chains, might protect this species from grazing pressure in the $\mathrm{AAZ}$ and contribute towards its ecological success (Hamm et al. 2003; Smetacek et al. 2004; Crosta et al. 2005).

Clustering analysis delineates groups of diatom species that were exported with a specific seasonality and the PLSR highlights the link between the timing of export of certain diatom groups and the BSi:POC signature of export. Although correlation coefficients are based on co-occurence and do not necessary imply causality, the observed relationships seem consistent with the ecological characteristics of the diatom species. For example $F$. kerguelensis and T. gracilis were present in export assemblages throughout the year with peaks in spring and summer and the PLSR suggests a positive correlation between the flux of these species and the BSi:POC ratio. This is consistent with the fact that Fragilariopsis is frequently observed as empty frustules in both natural and artificial fertilization experiments (Smetacek et al. 2004; Salter et al. 2012; Assmy et al. 2013). A detailed quantitative analysis of exported diatom assemblages from the productive waters of the central Kerguelen Plateau shows empty cells of F. kerguelensis and small centric species (comprising T. gracilis) dominating spring export fluxes coinciding with the lowest POC flux and the highest BSi:POC ratio (Rembauville et al. 2015a). These results suggest that these species with very robust frustules predominantly contribute to the export of silicon (Smetacek et al. 2004; Assmy et al. 2013). Other species displayed a clear mid-summer export peak and were 
clustered together such as CRS and Pseudo-Nitschia spp. These two diatom groups were found to be mostly exported as full cells in the productive area of the Kerguelen Plateau (Rembauville et al. 2015a). Consistently with that, Pseudo-nitzschia lineola, and Chaetoceros Hyalochaete were also positively associated with POC flux in a deeper (800 m) sediment trap in the Polar Frontal Zone south of Tasmania (Rigual-Hernández et al. 2015a). C. socialis displayed a clear mid-summer export peak and was also negatively correlated with the BSi:POC ratio. This lightly silicified species is thought to contribute predominantly to phytoaggregate formation (Alldredge et al. 1995) with a potentially important contribution to carbon export at the end of phytoplankton blooms (Booth et al. 2002).

The phytoplankton community at KERFIX is dominated at annual scale by small flagellates $(2-10 \mu \mathrm{m})$ and mostly represented by Prasinophyceae and Cryptophyceae (Fiala et al. 1998; Kopczyńska et al. 1998). Therefore, in contrast with a diatom-dominated system such as the central Kerguelen Plateau, the seasonality of the BSi:POC ratio at KERFIX is likely to be influenced by processes that are not quantified here (e.g. faecal pellet and/or nondiatom phytoplankton contribution to POC flux). However, the PLSR suggests that the diatom community structure remains an important ecological factor influencing the BSi:POC export ratio. A precise quantification of the fraction of full and empty cells (Assmy et al. 2013), together with the contribution of non-diatom cells and faecal pellets is necessary to fully quantify their relative contributions to POC flux (Rembauville et al. 2015a). Finally, the use of modern techniques allowing the quantification of the BSi content at the cellular level (e.g., Twining et al. 2004; Jungandreas et al. 2012) might help to refine the importance of diatom community structure for the BSi:POC stoichiometry of export at HNLC sites.

Calcifying planktonic organisms were not quantified in the export assemblages as part of the present study. Nevertheless, the seasonality of the PIC flux can be compared with the abundance of calcifying communities in the mixed layer. The marked increase in 
coccolithophore biomass in the mixed layer (Fiala et al. 1998; Kopczyńska et al. 1998) occurs concomitantly with the highest PIC flux observed in the sediment trap (from November 1994 to January 1995). Pteropods are a minor component ( $<7 \%$ of the mesozooplankton abundance) of the zooplankton assemblage at KERFIX in summer (Carlotti et al. 2008) and low foraminifera abundances are typical for the AAZ (Mortyn and Charles 2003; Bergami et al. 2009; Lombard et al. 2011). Coccolithophore-derived $\mathrm{CaCO}_{3}$ has been recently shown to dominate (85\%) PIC export at the productive A3 station (Rembauville et al. 2016b). During the 1993-1994 sediment trap deployment at KERFIX, Ternois et al. (1998) have reported the highest coccolith export flux (>99\% contributed by E. huxleyi) in January 1994 at the same period of the year than the highest PIC export we report in January 1995. These results implies that coccolithophores might also strongly contribute to PIC export under HNLC conditions, although a more detailed analysis of the exported calcifying plankton community is required to confirm this hypothesis.

\section{Comparison with the iron-fertilized productive central Kerguelen Plateau}

We carried out a comparison of water column and shallow sediment trap data from the KERFIX (HNLC) and nearby A3 site (productive) in an attempt to elucidate the impact of iron availability on production and export processes around the Kerguelen Plateau (Table 2). The annual sediment trap records at KERFIX and A3 are separated by 17 years and may themselves be influenced by inter annual variability and climate-driven, long-term trends possibly associated with changes in the plankton community structure (Alvain et al. 2013; Boyd et al. 2016, Davidson et al. 2016). However, there are no in situ data available at the two stations with a sufficient time coverage to quantify such climate-driven changes (Henson et al. 2016). Furthermore, the sediment traps deployed at KERFIX and A3 were different models (Technicap PPS5 and PPS3, respectively) that differ in their funnel shape and aspect ratio. We cannot eliminate the possibility that these designs may have been subject to different 
hydrodynamic and biological biases that alter the collection efficiency of sinking particles (Hawley 1988; Buesseler et al. 2007). Nevertheless, the low and tidal-driven circulation observed at both KERFIX and A3 (Rembauville et al. 2015b) should not result in large bias when flux estimates from both stations are compared.

An upper limit of $1 \mu \mathrm{g} \mathrm{L}^{-1}$ for chlorophyll $a$ concentration has been suggested as a threshold to define HNLC conditions (Tyrrell et al. 2005). Under this definition, the KERFIX station lies in the upper limit of what is considered as HNLC conditions. The annual POC flux at $300 \mathrm{~m}$ at KERFIX (52 mmol m $\left.\mathrm{mr}^{-2}\right)$ is in the same range as deep ocean POC fluxes reported from other non-fertilized areas of the AAZ $\left(33 \mathrm{mmol} \mathrm{m}^{-2} \mathrm{yr}^{-1}\right.$ at $2200 \mathrm{~m}$, Fischer et al. $2002,35 \mathrm{mmol} \mathrm{m}^{-2} \mathrm{yr}^{-1}$ at $1300 \mathrm{~m}$, Tesi et al. 2012, $102 \mathrm{mmol} \mathrm{m}^{-2} \mathrm{yr}^{-1}$ at $2000 \mathrm{~m}$ RigualHernández et al. 2015b). This suggests that important processes determining the magnitude of POC export in the AAZ occur in the upper layers of ocean.

One major difference between the two sites is a two-fold higher annual BSi:POC ratio under HNLC conditions. This is similar to the 2-3.5 fold difference in BSi:POC ratio found in deep sediment traps (>2000 m) between HNLC and iron-fertilized productive waters around the Crozet Plateau (Salter et al. 2012). At KERFIX the maximum fluxes of F. kerguelensis are one order of magnitude higher than at A3 and this species dominates the diatom export assemblage (60\%) at this HNLC site compared to at A3 (10\%, Rembauville et al. 2015a). F. kerguelensis is a strongly silicified species (Smetacek et al. 2004; Assmy et al. 2013) that likely contributes to the higher BSi:POC export ratio on seasonal and annual time scales (Rembauville et al. 2015a). Similar observations were made at Crozet where the fluxes of heavily silicified and/or large species (F. kerguelensis, $C$. pennatum and Dactyliosolen antarcticus) were higher under HNLC conditions (Salter et al. 2012). Although non-diatom components may influence POC fluxes, it is apparent that iron limitation favors the ecological 
selection of large and heavily silicified diatoms with a measurable and consistent effect on BSi:POC export stoichiometry (Smetacek et al. 2004).

Annual PIC export is similar at the KERFIX and A3 stations $\left(\sim 7 \mathrm{mmol} \mathrm{m}^{-2} \mathrm{yr}^{-1}\right)$. This is in stark contrast to the Crozet Plateau where deep-ocean PIC fluxes were 7-10 times higher at the iron-fertilized productive site (Salter et al. 2014b). These differences are likely related to the position of the two plateaus relative to the Polar and Subantarctic Fronts. Indeed the abundance of calcifying phyto- and zooplankton generally decreases south of the Polar Front (e.g., Mortyn and Charles 2003; Hunt et al. 2008; Saavedra-Pellitero et al. 2014), leading to a much lower PIC:POC export ratio (see a data compilation by Salter et al. 2014b).

Foraminifera are a dominant component of PIC fluxes at the Crozet Plateau north of the Polar Front and pteropod aragonite fluxes are notably enhanced (Salter et al. 2014b). In contrast, coccoliths of Emiliania huxleyi dominate the PIC export at A3 south of the Polar Front (Rembauville et al. 2016b) and it is likely that they also contributed to PIC export at KERFIX (Ternois et al. 1998). South of the Polar Front, the cosmopolitan species E. huxleyi dominates the coccolithophore community composition (Saavedra-Pellitero et al. 2014; Winter et al. 2014). This species is known to prevail under low iron concentrations (Brand et al. 1983; Muggli and Harrison 1997) and coccolithophore blooms are strongly temperature-dependant in the high latitude ocean (Sadeghi et al. 2012). Therefore, the similarity in nitrate and phosphate concentrations (Blain et al. 2015) and summer temperature may explain the similarity of PIC fluxes mechanisms at both KERFIX and A3. These results support the idea that the location of iron fertilization relative to the SAF and PF determines the magnitude of a carbonate counter pump effect due to frontal zonation of calcifying plankton assemblages (Salter et al. 2014b; Rembauville et al. 2016b).

The seasonal net community production $(\mathrm{NCP}$, net primary production minus heterotrophic respiration integrated during the productive period) derived from DIC budgets is 
two-fold higher at A3 compared to KERFIX, although maximum primary production levels are four-fold higher at A3 (Table 2). Similar to NCP, annual POC export is two-fold higher at A3. Hence, the fraction of net community production exported annually from the mixed layer is similar at the productive station A3 (1.5\%) and the HNLC station KERFIX (1.7\%).

However, it must be stressed that estimates of seasonal NCP rely on DIC distribution and are associated with important uncertainties (Jouandet et al. 2008), and potentially strong inter annual variability (Louanchi et al. 2001).

Despite the limitations outlined above our estimates suggest that the HNLC environment exports a similarly low fraction of seasonal NCP $(<10 \%$, assuming two-fold uncertainty on both NCP and export) when compared to a productive iron-fertilized regime (A3 station, Rembauville et al. 2015a). Previous short term estimates of production and export have demonstrated the inverse relationship between primary production and export efficiency in the Southern Ocean (Maiti et al. 2013). An artificial fertilization study concluded that iron addition does not increase the export efficiency at short time scales (Lam and Bishop 2007). Our findings support the notion that although natural iron fertilization in the Southern Ocean increases carbon export out of the mixed layer (Blain et al. 2007; Pollard et al. 2009), it does not appear to increase the efficiency the biological carbon export over annual timescales. These results highlight the need to study the ecosystem processes responsible for the low export efficiency to fully understand carbon pathways from primary production to export (Huntley et al. 1991; Lam and Bishop 2007; Stukel et al. 2015; Le Moigne et al. 2016). 


\section{Acknowledgments}

524 We thank Catherine Jeandel, P.I. of the KERFIX project. Diatom taxonomy analyses were

525 performed by J. J. Pichon at the EPOC laboratory. We thank Damien Cardinal for providing

526 the freeze-dried material for BSi analyses. The International Atomic Energy Agency is

527 grateful to the Government of the Principality of Monaco for the support provided to its

528 Environment Laboratories. This work was supported by the Centre National de la Recherche

529 Scientifique (CNRS - INSU), the Institut Polaire Paul Emile Victor (IPEV) and the project

530 SOCLIM of climate initiative (Fondation BNP Paribas). 


\section{References}

Abdi H (2010) Partial least squares regression and projection on latent structure regression (PLS Regression). Wiley Interdiscip Rev Comput Stat 2:97-106. doi: 10.1002/wics.51

Alldredge AL, Gotschalk C, Passow U, Riebesell U (1995) Mass aggregation of diatom blooms: Insights from a mesocosm study. Deep Sea Res Part 2 Top Stud Oceanogr 42:9-27. doi: 10.1016/0967-0645(95)000028

Alvain S, Le Quéré C, Bopp L, et al (2013) Rapid climatic driven shifts of diatoms at high latitudes. Remote Sens Environ 132:195-201. doi: 10.1016/j.rse.2013.01.014

Aminot A, Kerouel R (2007) Dosage automatique des nutriments dans les eaux marines: méthodes en flux continu. Ifremer, Plouzané, France

Assmy P, Smetacek V, Montresor M, et al (2013) Thick-shelled, grazer-protected diatoms decouple ocean carbon and silicon cycles in the iron-limited Antarctic Circumpolar Current. Proc Natl Acad Sci 110:20633-20638. doi: 10.1073/pnas.1309345110

Baker ET, Milburn HB, Tennant DA (1988) Field assessment of sediment trap efficiency under varying flow conditions. J Mar Res 46:573-592. doi: 10.1357/002224088785113522

Bárcena MA, Abrantes F (1998) Evidence of a high-productivity area off the coast of Málaga from studies of diatoms in surface sediments. Mar Micropaleontol 35:91-103. doi: 10.1016/S0377-8398(98)00012-7

Bergami C, Capotondi L, Langone L, et al (2009) Distribution of living planktonic foraminifera in the Ross Sea and the Pacific sector of the Southern Ocean (Antarctica). Mar Micropaleontol 73:37-48. doi: 10.1016/j.marmicro.2009.06.007

Blain S, Capparos J, Guéneuguès A, et al (2015) Distributions and stoichiometry of dissolved nitrogen and phosphorus in the iron-fertilized region near Kerguelen (Southern Ocean). Biogeosciences 12:623-635. doi: $10.5194 / \mathrm{bg}-12-623-2015$

Blain S, Quéguiner B, Armand L, et al (2007) Effect of natural iron fertilization on carbon sequestration in the Southern Ocean. Nature 446:1070-1074. doi: 10.1038/nature05700

Blain S, Quéguiner B, Trull T (2008) The natural iron fertilization experiment KEOPS (KErguelen Ocean and Plateau compared Study): An overview. Deep Sea Res Part 2 Top Stud Oceanogr 55:559-565. doi: 10.1016/j.dsr2.2008.01.002

Blain S, Tréguer P, Belviso S, et al (2001) A biogeochemical study of the island mass effect in the context of the iron hypothesis: Kerguelen Islands, Southern Ocean. Deep Sea Res Part 1 Oceanogr Res Pap 48:163187. doi: 10.1016/S0967-0637(00)00047-9

Booth BC, Larouche P, Bélanger S, et al (2002) Dynamics of Chaetoceros socialis blooms in the North Water. Deep Sea Res Part 2 Top Stud Oceanogr 49:5003-5025. doi: 10.1016/S0967-0645(02)00175-3

Boyd PW, Dillingham PW, McGraw CM, et al (2016) Physiological responses of a Southern Ocean diatom to complex future ocean conditions. Nature Clim Change 6:207-213. doi: 10.1038/nclimate2811

Boyd PW, Newton PP (1995) Evidence of the potential influence of planktonic community structure on the interannual variability of particulate organic carbon flux. Deep Sea Res Part 1 Oceanogr Res Pap 42:619-639. doi: 10.1016/0967-0637(95)00017-Z

Boyd PW, Newton PP (1999) Does planktonic community structure determine downward particulate organic carbon flux in different oceanic provinces? Deep Sea Res Part 1 Oceanogr Res Pap 46:63-91. doi: 10.1016/S0967-0637(98)00066-1

Brand LE, Sunda WG, Guillard RRL (1983) Limitation of marine phytoplankton reproductive rates by zinc, manganese, and iron. Limnol Oceanogr 28:1182-1198. doi: 10.4319/lo.1983.28.6.1182 
Buesseler KO, Antia AN, Chen M, et al (2007) An assessment of the use of sediment traps for estimating upper ocean particle fluxes. J Mar Res 65:345-416.

Buesseler KO, McDonnell AMP, Schofield OME, et al (2010) High particle export over the continental shelf of the west Antarctic Peninsula. Geophys Res Lett 37:L22606. doi: 10.1029/2010GL045448

Carlotti F, Thibault-Botha D, Nowaczyk A, Lefèvre D (2008) Zooplankton community structure, biomass and role in carbon fluxes during the second half of a phytoplankton bloom in the eastern sector of the Kerguelen Shelf (January-February 2005). Deep Sea Res Part 2 Top Stud Oceanogr 55:720-733. doi: 10.1016/j.dsr2.2007.12.010

Cavagna AJ, Fripiat F, Elskens M, et al (2015) Production regime and associated N cycling in the vicinity of Kerguelen Island, Southern Ocean. Biogeosciences 12:6515-6528. doi: 10.5194/bg-12-6515-2015

Cavan EL, Le Moigne FAC, Poulton AJ, et al (2015) Zooplankton fecal pellets control the attenuation of particulate organic carbon flux in the Scotia Sea, Southern Ocean. Geophys Res Lett 2014GL062744. doi: 10.1002/2014GL062744

Coppola L, Roy-Barman M, Wassmann P, et al (2002) Calibration of sediment traps and particulate organic carbon export using ${ }^{234}$ Th in the Barents Sea. Mar Chem 80:11-26. doi: 10.1016/S03044203(02)00071-3

Crosta X, Romero O, Armand LK, Pichon J-J (2005) The biogeography of major diatom taxa in Southern Ocean sediments: 2. Open ocean related species. Palaeogeogr Palaeoclimatol Palaeoecol 223:66-92. doi: 10.1016/j.palaeo.2005.03.028

Davidson AT, McKinley J, Westwood K, et al (2016) Enhanced $\mathrm{CO}_{2}$ concentrations change the structure of Antarctic marine microbial communities. Mar Ecol Prog Ser 552:93-113. doi: 10.3354/meps11742

de Baar HJW, Buma AGJ, Nolting RF, et al (1990) On iron limitation of the Southern Ocean: Experimental observations in the Weddell and Scotia Seas. Mar Ecol Prog Ser 65:105-122. doi: 10.3354/meps065105

de Baar HJW, de Jong JTM, Bakker DCE, et al (1995) Importance of iron for plankton blooms and carbon dioxide drawdown in the Southern Ocean. Nature 373:412-415. doi: 10.1038/373412a0

Dehairs F, Jeandel C, Cattaldo T, et al (1996) Barium-barite as a tracer of export production: some information from the water column. In: Ragueneau O (ed) Proceedings of the symposium OPALEO. Brest, pp 175192

DeMaster DJ (1981) The supply and accumulation of silica in the marine environment. Geochim Cosmochim Acta 45:1715-1732. doi: 10.1016/0016-7037(81)90006-5

Fiala M, Kopczynska EE, Jeandel C, et al (1998) Seasonal and interannual variability of size-fractionated phytoplankton biomass and community structure at station Kerfix, off the Kerguelen Islands, Antarctica. J Plankton Res 20:1341-1356. doi: 10.1093/plankt/20.7.1341

Fischer G, Gersonde R, Wefer G (2002) Organic carbon, biogenic silica and diatom fluxes in the marginal winter sea-ice zone and in the Polar Front Region: Interannual variations and differences in composition. Deep Sea Res Part 2 Top Stud Oceanogr 49:1721-1745. doi: 10.1016/S0967-0645(02)00009-7

Gardner WD (1980) Field assessment of sediment traps. J Mar Res 38:41-52.

Grigorov I, Rigual-Hernandez AS, Honjo S, et al (2014) Settling fluxes of diatoms to the interior of the Antarctic circumpolar current along $170^{\circ} \mathrm{W}$. Deep Sea Res Part 1 Oceanogr Res Pap 93:1-13. doi: 10.1016/j.dsr.2014.07.008

Guidi L, Legendre L, Reygondeau G, et al (2015) A new look at ocean carbon remineralization for estimating deepwater sequestration. Glob Biogeochem Cycles 29:1044-1059. doi: 10.1002/2014GB005063 
Hamm CE, Merkel R, Springer O, et al (2003) Architecture and material properties of diatom shells provide effective mechanical protection. Nature 421:841-843. doi: 10.1038/nature01416

Hasle GR, Syvertsen EE (1997) Chapter 2 - Marine Diatoms. In: Tomas CR (ed) Identifying Marine Phytoplankton. Academic Press, San Diego, pp 5-385

Hawley N (1988) Flow in Cylindrical Sediment Traps. J Great Lakes Res 14:76-88. doi: 10.1016/S03801330(88)71534-8

Henson SA, Beaulieu C, Lampitt R (2016) Observing climate change trends in ocean biogeochemistry: When and where. Glob Chang Biol 22:1561-1571. doi: 10.1111/gcb.13152

Hunt BPV, Pakhomov EA, Hosie GW, Siegel V, Ward P, Bernard K (2008) Pteropods in Southern Ocean ecosystems. Prog Oceanogr 78, 193-221. doi:10.1016/j.pocean.2008.06.001

Huntley ME, Lopez MD, Karl DM (1991) Top predators in the Southern ocean: A major leak in the biological carbon pump. Science 253:64-66. doi: 10.1126/science.1905841

Jacquet SH., Lam PJ, Trull T, Dehairs F (2011) Carbon export production in the subantarctic zone and polar front zone south of Tasmania. Deep Sea Res Part 2 Top Stud Oceanogr 58:2277-2292. doi: 10.1016/j.dsr2.2011.05.035

Jeandel C, Ruiz-Pino D, Gjata E, et al (1998) KERFIX, a time-series station in the Southern Ocean: A presentation. J Mar Syst 17:555-569. doi: 10.1016/S0924-7963(98)00064-5

Jouandet MP, Blain S, Metzl N, et al (2008) A seasonal carbon budget for a naturally iron-fertilized bloom over the Kerguelen Plateau in the Southern Ocean. Deep Sea Res Part 2 Top Stud Oceanogr 55:856-867. doi: $10.1016 /$ j.dsr2.2007.12.037

Jungandreas A, Wagner H, Wilhelm C (2012) Simultaneous measurement of the silicon content and physiological parameters by FTIR spectroscopy in diatoms with siliceous cell walls. Plant Cell Physiol 53:2153-2162. doi: 10.1093/pcp/pcs144

Kopczyńska EE, Fiala M, Jeandel C (1998) Annual and interannual variability in phytoplankton at a permanent station off Kerguelen Islands, Southern Ocean. Polar Biol 20:342-351. doi: 10.1007/s003000050312

Lam PJ, Bishop JKB (2007) High biomass, low export regimes in the Southern Ocean. Deep Sea Res Part 2 Top Stud Oceanogr 54:601-638. doi: 10.1016/j.dsr2.2007.01.013

Lam PJ, Doney SC, Bishop JKB (2011) The dynamic ocean biological pump: insights from a global compilation of particulate organic carbon, $\mathrm{CaCO}_{3}$, and opal concentration profiles from the mesopelagic. Glob Biogeochem Cycles 25:GB3009. doi: 10.1029/2010GB003868

Laurenceau-Cornec EC, Trull TW, Davies DM, et al (2015) Phytoplankton morphology controls on marine snow sinking velocity. Mar Ecol Prog Ser 520:35-56. doi: 10.3354/meps11116

Laws EA, D’Sa E, Naik P (2011) Simple equations to estimate ratios of new or export production to total production from satellite-derived estimates of sea surface temperature and primary production. Limnol Oceanogr Methods 9:593-601. doi: 10.4319/lom.2011.9.593

Le Moigne FAC, Henson SA, Cavan E, et al (2016) What causes the inverse relationship between primary production and export efficiency in the Southern Ocean? Geophys Res Lett 2016GL068480. doi: 10.1002/2016GL068480

Lombard F, Labeyrie L, Michel E, et al (2011) Modelling planktic foraminifer growth and distribution using an ecophysiological multi-species approach. Biogeosciences 8:853-873. doi: 10.5194/bg-8-853-2011

Louanchi F, Ruiz-Pino DP, Jeandel C, et al (2001) Dissolved inorganic carbon, alkalinity, nutrient and oxygen seasonal and interannual variations at the Antarctic Ocean JGOFS-KERFIX site. Deep Sea Res Part 1 Oceanogr Res Pap 48:1581-1603. doi: 10.1016/S0967-0637(00)00086-8 
Maiti K, Charette MA, Buesseler KO, Kahru M (2013) An inverse relationship between production and export efficiency in the Southern Ocean. Geophys Res Lett 40:1557-1561. doi: 10.1002/grl.50219

Maraldi C, Lyard F, Testut L, Coleman R (2011) Energetics of internal tides around the Kerguelen Plateau from modeling and altimetry. J Geophys Res Oceans 116:C06004. doi: 10.1029/2010JC006515

Martin JH, Gordon RM, Fitzwater SE (1990) Iron in Antarctic waters. Nature 345:156-158. doi: $10.1038 / 345156 \mathrm{a} 0$

Matsuno K, Yamaguchi A, Fujiwara A, et al (2014) Seasonal changes in mesozooplankton swimmers collected by sediment trap moored at a single station on the Northwind Abyssal Plain in the western Arctic Ocean. J Plankton Res 36, 490-502. doi:10.1093/plankt/fbt092

McEwen GF, Johnson MW, Folsom TR (1954) A statistical analysis of the performance of the folsom plankton sample splitter, based upon test observations. Arch Meteorol Geophys Biocl A 7:502-527. doi: 10.1007/BF02277939

McQuoid MR, Hobson LA (1996) Diatom Resting Stages. J Phycol 32:889-902. doi: 10.1111/j.00223646.1996.00889.x

Merlivat L, Boutin J, Antoine D (2015) Roles of biological and physical processes in driving seasonal air-sea $\mathrm{CO}_{2}$ flux in the Southern Ocean: New insights from CARIOCA $\mathrm{pCO}_{2}$. J Mar Syst 147:9-20. doi: 10.1016/j.jmarsys.2014.04.015

Minas H, Minas M (1992) Net community production in high nutrient-low chlorophyll waters of the tropical and antarctic oceans - grazing vs iron hypothesis. Oceanol Acta 15:145-162.

Minas HJ, Minas M, Packard TT (1986) Productivity in upwelling areas deduced from hydrographic and chemical fields. Limnol Oceanogr 31:1182-1206. doi: 10.4319/lo.1986.31.6.1182

Miquel JC, Fowler SW, La Rosa J, Buat-Menard P (1994) Dynamics of the downward flux of particles and carbon in the open northwestern Mediterranean Sea. Deep Sea Res Part 1 Oceanogr Res Pap 41:243261. doi: 10.1016/0967-0637(94)90002-7

Moore CM, Hickman AE, Poulton AJ, et al (2007) Iron-light interactions during the CROZet natural iron bloom and EXport experiment (CROZEX): II-Taxonomic responses and elemental stoichiometry. Deep Sea Res Part 2 Top Stud Oceanogr 54:2066-2084. doi: 10.1016/j.dsr2.2007.06.015

Morris, P.J., Sanders, R., Turnewitsch, R., Thomalla, S., (2007) ${ }^{234}$ Th-derived particulate organic carbon export from an island-induced phytoplankton bloom in the Southern Ocean. Deep Sea Res Part 2 Top Stud Oceanogr 54:2208-2232. doi:10.1016/j.dsr2.2007.06.002

Mortyn PG, Charles CD (2003) Planktonic foraminiferal depth habitat and $\delta 180$ calibrations: Plankton tow results from the Atlantic sector of the Southern Ocean. Paleoceanography 18:1037. doi: 10.1029/2001PA000637

Mosseri J, Quéguiner B, Armand L, Cornet-Barthaux V (2008) Impact of iron on silicon utilization by diatoms in the Southern Ocean: A case study of Si/N cycle decoupling in a naturally iron-enriched area. Deep Sea Res Part 2 Top Stud Oceanogr 55:801-819. doi: 10.1016/j.dsr2.2007.12.003

Mosseri J, Quéguiner B, Rimmelin P, et al (2005) Silica fluxes in the northeast Atlantic frontal zone of Mode Water formation $\left(38^{\circ}-45^{\circ} \mathrm{N}, 16^{\circ}-22^{\circ} \mathrm{W}\right)$ in 2001-2002. J Geophys Res Oceans 110:C07S19. doi: $10.1029 / 2004 \mathrm{JC} 002615$

Muggli DL, Harrison PJ (1997) Effects of iron on two oceanic phytoplankters grown in natural NE subarctic pacific seawater with no artificial chelators present. J Exp Mar Biol Ecol 212:225-237. doi: 10.1016/S0022-0981(96)02752-9

Nodder SD, Alexander BL (1999) The effects of multiple trap spacing, baffles and brine volume on sediment trap collection efficiency. J Mar Res 57:537-559. doi: 10.1357/002224099764805183 
Obernosterer I, Christaki U, Lefèvre D, et al (2008) Rapid bacterial mineralization of organic carbon produced during a phytoplankton bloom induced by natural iron fertilization in the Southern Ocean. Deep Sea Res Part 2 Top Stud Oceanogr 55:777-789. doi: 10.1016/j.dsr2.2007.12.005

Park Y-H, Charriaud E, Pino DR, Jeandel C (1998) Seasonal and interannual variability of the mixed layer properties and steric height at station KERFIX, southwest of Kerguelen. J Mar Syst 17:571-586. doi: 10.1016/S0924-7963(98)00065-7

Park Y-H, Fuda J-L, Durand I, Naveira Garabato AC (2008a) Internal tides and vertical mixing over the Kerguelen Plateau. Deep Sea Res Part 2 Top Stud Oceanogr 55:582-593. doi: 10.1016/j.dsr2.2007.12.027

Park Y-H, Roquet F, Durand I, Fuda J-L (2008b) Large-scale circulation over and around the Northern Kerguelen Plateau. Deep Sea Res Part 2 Top Stud Oceanogr 55:566-581. doi: 10.1016/j.dsr2.2007.12.030

Planchon F, Ballas D, Cavagna A-J, et al (2015) Carbon export in the naturally iron-fertilized Kerguelen area of the Southern Ocean based on the ${ }^{234} \mathrm{Th}$ approach. Biogeosciences 12:3831-3848. doi: 10.5194/bg-12$3831-2015$

Pollard R, Sanders R, Lucas M, Statham P (2007) The Crozet natural iron bloom and export experiment (CROZEX). Deep Sea Res Part 2 Top Stud Oceanogr 54:1905-1914. doi: 10.1016/j.dsr2.2007.07.023

Pollard RT, Salter I, Sanders RJ, et al (2009) Southern Ocean deep-water carbon export enhanced by natural iron fertilization. Nature 457:577-580. doi: 10.1038/nature07716

Pondaven P, Fravalo C, Ruiz-Pino D, et al (1998) Modelling the silica pump in the Permanently Open Ocean Zone of the Southern Ocean. J Mar Syst 17:587-619. doi: 10.1016/S0924-7963(98)00066-9

Pondaven P, Ruiz-Pino D, Fravalo C, et al (2000) Interannual variability of Si and N cycles at the time-series station KERFIX between 1990 and 1995 - a 1-D modelling study. Deep Sea Res Part 1 Oceanogr Res Pap 47:223-257. doi: 10.1016/S0967-0637(99)00053-9

Quéguiner B (2013) Iron fertilization and the structure of planktonic communities in high nutrient regions of the Southern Ocean. Deep Sea Res Part 2 Top Stud Oceanogr 90:43-54. doi: 10.1016/j.dsr2.2012.07.024

Razouls S, Réau GD, Guillot P, et al (1998) Seasonal abundance of copepod assemblages and grazing pressure in the Kerguelen Island area (Southern Ocean). J Plankton Res 20:1599-1614. doi: 10.1093/plankt/20.8.1599

Rembauville M, Blain S, Armand L, et al (2015a) Export fluxes in a naturally iron-fertilized area of the Southern Ocean - Part 2: Importance of diatom resting spores and faecal pellets for export. Biogeosciences 12:3171-3195. doi: 10.5194/bg-12-3171-2015

Rembauville M, Manno C, Tarling GA, et al (2016a) Strong contribution of diatom resting spores to deep-sea carbon transfer in naturally iron-fertilized waters downstream of South Georgia. Deep Sea Res Part 1 Oceanogr Res Pap 115:22-35. doi: 10.1016/j.dsr.2016.05.002

Rembauville M, Meilland J, Ziveri P, et al (2016b) Planktic foraminifer and coccolith contribution to carbonate export fluxes over the central Kerguelen Plateau. Deep Sea Res Part 1 Oceanogr Res Pap 111:91-101. doi: 10.1016/j.dsr.2016.02.017

Rembauville M, Salter I, Leblond N, et al (2015b) Export fluxes in a naturally iron-fertilized area of the Southern Ocean - Part 1: Seasonal dynamics of particulate organic carbon export from a moored sediment trap. Biogeosciences 12:3153-3170. doi: 10.5194/bg-12-3153-2015

Rigual-Hernández AS, Trull TW, Bray SG, et al (2015a) Latitudinal and temporal distributions of diatom populations in the pelagic waters of the Subantarctic and Polar Frontal zones of the Southern Ocean and their role in the biological pump. Biogeosciences 12:5309-5337. doi: 10.5194/bg-12-5309-2015 
Rigual-Hernández AS, Trull TW, Bray SG, et al (2015b) Seasonal dynamics in diatom and particulate export fluxes to the deep sea in the Australian sector of the southern Antarctic Zone. J Mar Syst 142:62-74. doi: $10.1016 /$ j.jmarsys.2014.10.002

Romero OE, Armand L (2010) Marine diatoms as indicators of modern changes in oceanographic conditions. In: Smol J, Stoermer E (ed) The diatoms: applications for the environmental and earth sciences. Cambridge University Press, Cambridge, pp 373-400. doi:10.1017/CBO9780511763175.021

Romero OE, Lange CB, Fisher G, et al (1999) Variability in export prodution documented by downward fluxes and species composition of marine planktonic diatoms: observations from the tropical and equatorial Atlantic. In: Fischer G, Wefer G (ed) The use of proxies in paleoceanography, examples from the South Atlantic, Springer, Berlin, pp 365-392. doi:10.1007/978-3-642-58646-0_14

Saavedra-Pellitero M, Baumann K-H, Flores J-A, Gersonde R (2014) Biogeographic distribution of living coccolithophores in the Pacific sector of the Southern Ocean. Mar Micropaleontol 109:1-20. doi: 10.1016/j.marmicro.2014.03.003

Sadeghi A, Dinter T, Vountas M, et al (2012) Remote sensing of coccolithophore blooms in selected oceanic regions using the PhytoDOAS method applied to hyper-spectral satellite data. Biogeosciences 9:21272143. doi: $10.5194 /$ bg-9-2127-2012

Salter I, Galand PE, Fagervold SK, et al (2014a) Seasonal dynamics of active SAR11 ecotypes in the oligotrophic Northwest Mediterranean Sea. ISME J. doi: 10.1038/ismej.2014.129

Salter I, Kemp AES, Moore CM, et al (2012) Diatom resting spore ecology drives enhanced carbon export from a naturally iron-fertilized bloom in the Southern Ocean. Glob Biogeochem Cycles 26:GB1014. doi: 10.1029/2010GB003977

Salter I, Lampitt RS, Sanders R, et al (2007) Estimating carbon, silica and diatom export from a naturally fertilised phytoplankton bloom in the Southern Ocean using PELAGRA: A novel drifting sediment trap. Deep Sea Res Part 2 Top Stud Oceanogr 54:2233-2259. doi: 10.1016/j.dsr2.2007.06.008

Salter I, Schiebel R, Ziveri P, et al (2014b) Carbonate counter pump stimulated by natural iron fertilization in the Polar Frontal Zone. Nat Geosci 7:885-889. doi: 10.1038/ngeo2285

Savoye N, Trull TW, Jacquet SHM, et al (2008) ${ }^{234}$ Th-based export fluxes during a natural iron fertilization experiment in the Southern Ocean (KEOPS). Deep Sea Res Part 2 Top Stud Oceanogr 55:841-855. doi: 10.1016/j.dsr2.2007.12.036

Schrader HJ, Gersonde R (1978) Diatoms and silicofagellates. Micropaleontological counting methods and techniques: an exercise on an eight metres section of the Lower Pliocene of Capo Rosello, Sicily. Utrecht Micropaleontol Bull 129-176.

Schulz M, Mudelsee M (2002) REDFIT: Estimating red-noise spectra directly from unevenly spaced paleoclimatic time series. Comput Geosci 28:421-426. doi: 10.1016/S0098-3004(01)00044-9

Sell DW, Evans MS (1982) A statistical analysis of subsampling and an evaluation of the Folsom plankton splitter. Hydrobiologia 94:223-230. doi: 10.1007/BF00016403

Smetacek V, Assmy P, Henjes J (2004) The role of grazing in structuring Southern Ocean pelagic ecosystems and biogeochemical cycles. Antarct Sci 16:541-558. doi: 10.1017/S0954102004002317

Smetacek V, Klaas C, Strass VH, et al (2012) Deep carbon export from a Southern Ocean iron-fertilized diatom bloom. Nature 487:313-319. doi: 10.1038/nature11229

Stukel MR, Asher E, Couto N, et al (2015) The imbalance of new and export production in the western Antarctic Peninsula, a potentially "leaky" ecosystem. Glob Biogeochem Cycles 29:2015GB005211. doi: 10.1002/2015GB005211 
Tarling GA, Ward P, Atkinson A, et al (2012) DISCOVERY 2010: Spatial and temporal variability in a dynamic polar ecosystem. Deep Sea Res Part 2 Top Stud Oceanogr 59-60:1-13. doi: 10.1016/j.dsr2.2011.10.001

Ternois Y, Sicre M-A, Boireau A, et al (1998) Hydrocarbons, sterols and alkenones in sinking particles in the Indian Ocean sector of the Southern Ocean. Org Geochem 28:489-501. doi: 10.1016/S01466380(98)00008-4

Tesi T, Langone L, Ravaioli. M, et al (2012) Particulate export and lateral advection in the Antarctic Polar Front (Southern Pacific Ocean): one-year mooring deployment. J Mar Syst 105-108:70-81. doi: 10.1016/j.jmarsys.2012.06.002

Twining BS, Baines SB, Fisher NS (2004) Element stoichiometries of individual plankton cells collected during the Southern Ocean Iron Experiment (SOFeX). Limnol Oceanogr 49:2115-2128. doi: 10.4319/lo.2004.49.6.2115

Tyrrell T, Merico A, Waniek JJ, et al (2005) Effect of seafloor depth on phytoplankton blooms in high-nitrate, low-chlorophyll (HNLC) regions. J Geophys Res Biogeosci 110:G02007. doi: 10.1029/2005JG000041

Winter A, Henderiks J, Beaufort L, et al (2014) Poleward expansion of the coccolithophore Emiliania huxleyi. J Plankton Res 36:316-325. doi: 10.1093/plankt/fbt110

Zielinski U, Gersonde R (1997) Diatom distribution in Southern Ocean surface sediments (Atlantic sector): Implications for paleoenvironmental reconstructions. Palaeogeogr Palaeoclimatol Palaeoecol 129:213250. doi: 10.1016/S0031-0182(96)00130-7 
Fig. 1: a) Location of the sediment trap studies in the Southern Ocean for which export fluxes

810 of particulate organic matter and diatom are reported over a complete annual cycle. b) Map of the Kerguelen Plateau showing the location of annual sediment trap deployments at the KERFIX station (this study) and A3 station (Rembauville et al. 2015a,b). Grey scale corresponds to a 15-year climatology (1997-2013) of satellite-derived chlorophyll $a$ (Globcolour). The dashed line represents a $0.5 \mu \mathrm{g} \mathrm{L}{ }^{-1}$ value and highlights difference between the productive central Kerguelen Plateau and HNLC area to the West. The black contour line represents the $1000 \mathrm{~m}$ isobath and the arrow denotes the approximate Polar Front (PF) location.

Fig. 2: Hydrological properties recorded by the moored instruments deployed on the sediment trap mooring: a) Trap depth variation, b) temperature and c) current speed. Grey lines are raw data, black lines are filtered data using a moving average with a 2 days window.

Fig. 3: Hydrodynamics at the sediment trap deployment location. a) Progressive vector diagram showing water displacement integrated over the sediment trap deployment period. The first day of each month is shown by a circle. b) Wind rose plot of current speed and direction. Grey circles are the probability distribution drawn every $2 \%$ from 0 to $10 \%$. c) Power spectrum resulting from the spectral analysis of the current speed. Dotted line represents $99 \%$ probability threshold for a random red noise distribution.

Fig. 4: Phytoplankton biomass and particulate export. a) Chlorophyll $a$ concentration in the upper $300 \mathrm{~m}$ at the KERFIX station, original monthly measurements are shown by black dots, redrawn from Fiala et al. (1998). Dotted line denotes the mixed layer depth from Park et al. (1998). b) Particulate organic carbon (POC) and inorganic carbon (PIC) fluxes recoded by the 
831 sediment trap at $280 \mathrm{~m}$. c) Biogenic silica (BSi) and BSi:POC molar ratio of the exported

832 particles.

833 Fig. 5: Diatom export fluxes measured in the sediment trap. a) Total diatom valve flux and b)-

834 1) diatom valve flux for species accounting for $>1 \%$ of the annually-integrated diatom valve

835 flux (grey bars). Numbers in bracket refer to the relative contribution of each species to total

836 diatom valves following integration over the entire deployment period. The relative

837 contribution of each species to the diatom assemblage is shown by dots and lines. CRS:

838 Chaetoceros subgenus Hyalochaete resting spores.

839 Fig. 6: Clustering of diatom species and association with the BSi:POC ratio. a) Dendrogram

840 based on diatom valve flux (Bray-curtis distance, UPGMA aggregation) for diatom species

841 contributing to $>1 \%$ of the total annual valve export. b) Correlation coefficients ( $\beta$ ) from a

842 PLSR between the diatom valve fluxes and the BSi:POC molar ratio $\left(\mathrm{R}^{2}=0.68\right.$, analysis

843 performed on standardized variables). 